\title{
Online accommodation booking habits and attitudes of Serbian travelers
}

\author{
Zoran Kalinić $^{1 *}$, Miloš Novaković ${ }^{2}$ \\ ${ }^{1}$ University of Kragujevac, Faculty of Economics, Kragujevac, Serbia \\ ${ }^{2}$ Comtrade, Kragujevac, Serbia
}

\begin{abstract}
The Internet and its services nowadays have significant influence on the organization of our travel arrangements, starting from information gathering to final booking and payment and they are the major distribution channel for travel services and products. The focus of the paper is on digital accommodation platforms, which enable users to search, explore, compare, book and pay online for accommodation all over the world. The study presents habits and attitudes of Serbian consumers to digital travel purchases, particularly accommodation booking. First, the most significant models of online booking systems, such as hotel websites, online tourist agencies and dedicated accommodation booking platforms are presented and compared. The analysis of the habits of Serbian travelers showed that they very often use various websites and online platforms to book their travels, but also that they prefer well-established international platforms, such as Booking.com and Airbnb. They also use online booking more when staying abroad than for domestic stays, and usually book shorter and cheaper travels and stays. As a key advantages of online booking systems, respondents stated wider variety of the offer and time and money savings.
\end{abstract}

Keywords: online booking, online booking platforms, tourism, Booking, Airbnb JEL classification: L81, L83, L86, R31, Z32

\section{Navike i stavovi srpskih putnika o rezervaciji smeštaja na Internetu}

Sažetak: Internet i njegovi servisi danas imaju značajan uticaj na organizaciju naših aranžmana za putovanja, počev od prikupljanja informacija do konačne rezervacije i plaćanja i oni su glavni kanal distribucije turističkih usluga i proizvoda. Fokus rada je na digitalnim platformama za smeštaj, koje korisnicima omogućavaju da pretražuju, istražuju, porede, rezervišu i plaćaju za smeštaj širom sveta, sve putem Interneta. Studija predstavlja navike i stavove srpskih potrošača o digitalnoj kupovini putovanja, posebno o rezervaciji smeštaja. Prvo, predstavljeni su i upoređeni najznačajniji modeli rezervacionih sistema na Internetu, kao što su sajtovi hotela, internet turističke agencije i namenske platforme za rezervaciju smeštaja. Analiza navika srpskih putnika pokazala je da oni veoma često koriste razne sajtove i digitalne platforme da rezervišu svoja putovanja, ali i da više vole poznate međunarodne platforme, kao što su Booking.com i Airbnb. Takođe, sisteme za onlajn rezervacije koriste češće za boravak u inostranstvu, nego za boravak u zemlji, a obično

\footnotetext{
* zkalinic@kg.ac.rs

** Research Project III-44010 of the Ministry of Education, Science and Technological Development of the Republic of Serbia.
} 
Kalinić, Z., Novaković, M. - Online accommodation booking habits and attitudes of Serbian travelers Hotel and Tourism Management, 2019, Vol. 7, No. 2: 11-23.

rezervišu kraća i jeftinija putovanja i boravke. Kao ključne prednosti digitalnih sistema za rezervacije ispitanici su naveli širi izbor ponude i uštede vremena i novca.

Ključne reči: rezervacije smeštaja na Internetu, platforme za rezervacije na Internetu, turizam, Booking, Airbnb

JEL klasifikacija: L81, L83, L86, R31, Z32

\section{Introduction}

The rise of Internet usage has opened new business possibilities in many areas, including traveling. The Internet has dramatically changed the way in which consumers book and organize their travel arrangements (Žmuk \& Mihajlović, 2018) and it is at the moment the major distribution channel for travel services and products (Amaro \& Duarte, 2016). In the last decade, electronic commerce in the areas of hospitality and tourism has advanced from the sales of simple travel products such as airline tickets, accommodations and car rentals, to more complex travel products, such as vacation packages and cruises (Bilgihan \& Bujisic, 2015).

eMarketer (2018) estimates that worldwide digital travel sales, which include airline, car rental, cruise, hotel, accommodation and transportation, were \$694 billion in 2018 and that they will reach $\$ 931$ billion in 2022. Asia-Pacific region surpassed North America as the leading digital travel market in the world, mainly due to high growth rates in China and India (eMarketer, 2017). Although the US is still the leading country in digital travel sales (holding more than $30 \%$ of worldwide digital travel sales in 2017), China, at the second position, has a much higher growth rate, threatening to take the leading position. Recent estimates show that more than 840 million consumers already use online systems to book hotels, package holidays, vacation rentals and cruises, and that this number will be higher than one billion by 2023 (Statista, 2019). Based on Google data, more than $80 \%$ of consumers make an online research to organize their holidays, visiting 26 websites on average and spending more than 2 hours in online search for the right place and the right offer (Filieri et al., 2015). This online search often includes the analysis of social networks and travel recommendation websites.

Out of many travel products and services, the focus of this paper is on online accommodation booking. Namely, one of the most popular and important steps consumers take when organizing a trip is online search for and booking of accommodation (Chaw \& Tang, 2019). Bilgihan and Bujisic (2015) reported that hotel reservations are the second most frequently purchased travel product online, after flight tickets. Accommodation booking websites, such as Booking.com and Airbnb, usually offer many relevant information, such as detailed accommodation description (including more photos and videos), pricing, customer review ratings and reviewers' comments, and finally the online booking and payment (Chaw \& Tang, 2019). Additional benefits of online accommodation booking are convenience and cost/time savings (Lien et al., 2015). Reports say that, by the number of total visits worldwide in 2017, the leader was Booking.com (with 336 million visits), followed by Airbnb (69.5 million), Expedia (59.4 million), Hotels.com (57.6 million), etc. (Chaw \& Tang, 2019). Additionally, consumers often use comparison or referral websites, such as Trivago or TripAdvisor, which aggregate prices from different travel websites and enable consumers to compare accommodation options and prices.

Therefore, the objective of this paper is to analyze main online platforms for accommodation booking, as well as consumer behavior and predictors of intention to book accommodation online. Particularly, the study will deal with habits, opinions and intentions to use online accommodation bookings of Serbian consumers. 


\section{Online platforms for accommodation booking}

As already stated, nowadays the Internet and its services represent one of the most important channels for marketing and distribution of all kinds of products and services, including travel and leisure. Despite still significant "digital divide" among European countries and between different socio-economic groups within the countries (e.g. different gender, age, education level, etc.), the number of Internet users is on the rise for many years. According to Eurostat (2018a) data, on average 84\% of the citizens of the European Union (EU) and 70\% of the citizens of the Republic of Serbia use the Internet on a regular basis. Travel services are one of the most frequently purchased products online and 53\% of all digital purchases in the EU include travel and holiday accommodation (Confente \& Vigolo, 2018). Statistics say that $42 \%$ of EU population and 24\% of Serbian population in 2017 used the Internet for travel and accommodation services (Eurostat, 2018b). The percentages of Internet users, consumers that use the Internet for travel and accommodation services, and use websites or apps to arrange accommodation from another individual, across EU countries and Serbia, are presented in Figure 1. As it can be seen, the leading EU country in using the Internet as the tool for travel and accommodation services is Luxemburg, with $71 \%$ of its inhabitants regularly using these online services, followed by Finland (61\%) and Denmark and Germany (58\%), while on the very end of the list are Bulgaria, with only $11 \%$, and Romania (12\%).

Figure 1: Using the Internet as the tool for travel and accommodation services 120

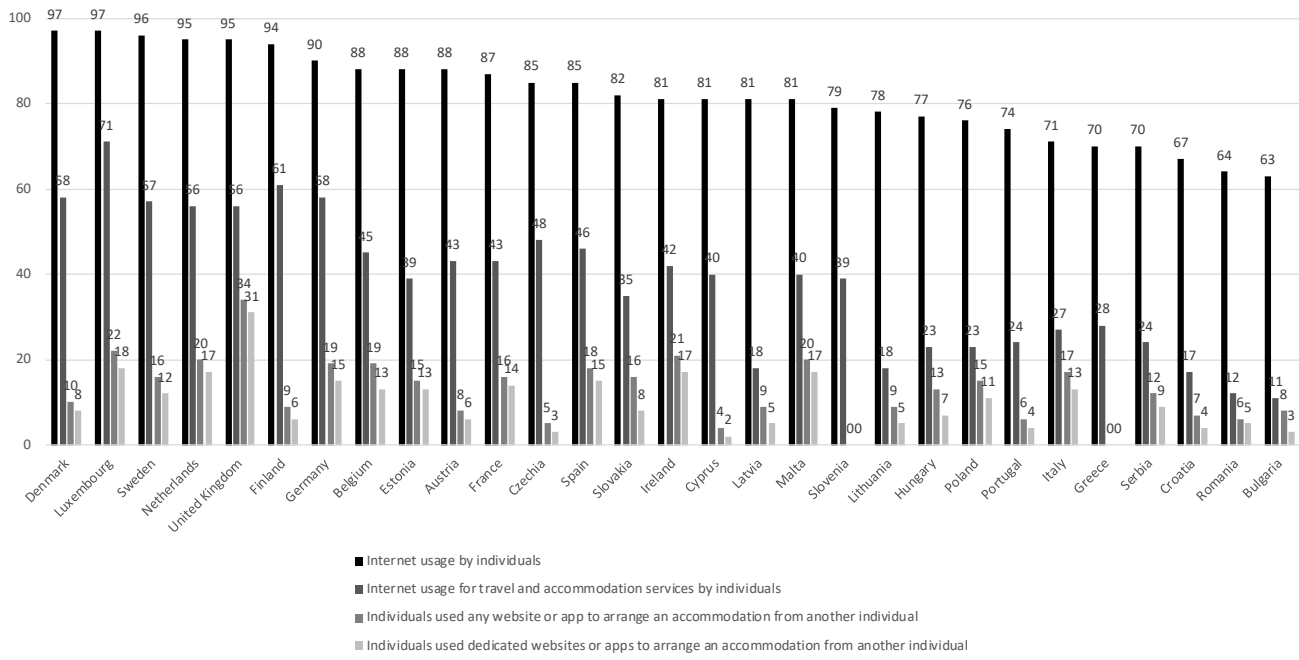

Source: Eurostat (2018a, 2018b, 2018c)

There are various business models of the companies offering short-time accommodation online, starting with hotel websites, where consumers directly book a room or an apartment. But, the costs of website development and maintenance are often too high, particularly for economy hotels, and they often rely on online travel agencies (Li et al., 2017). Online travel agencies (OTA), such as Expedia or Travelocity, offer accommodation of its partners, but also offer other travel products and services, such as flight tickets, rent-a-car, travel insurance, cruises, etc. This may be a very successful business model, as consumer can, at the same place, compare the offers and choose and book the most appropriate one, also combining it with, for example, flight tickets. Customers satisfied with hotel services may 
Kalinić, Z., Novaković, M. - Online accommodation booking habits and attitudes of Serbian travelers Hotel and Tourism Management, 2019, Vol. 7, No. 2: 11-23.

rebook the hotels through OTA but they might also use hotel websites for the next visits. Therefore, OTAs and hotels cooperate to attract new customers to hotels, but after the first visit, they actually compete for customer loyalty (Chang et al., 2019).

A similar business model includes platforms which aggregate accommodation offers from different subjects (mainly hotel owners) and the most famous is Booking.com. Established in 1996 in Amsterdam as a small start-up company, Booking.com today is one of the largest online accommodation booking companies in the world, with almost 30 million accommodation units in over 150.000 destinations in 228 countries and territories (Booking, 2019). Each day more than 1.5 million overnight stays are booked using this platform. Booking.com is particularly useful for small and independent hotels, with weak brand positioning and limited promotional resources compared to large, well-known hotel chains (Akbar \& Tracogna, 2018).

Finally, the latest innovation in this area are web platforms dominantly focused on the accommodation offered by individuals (C2C or Consumer-to-Consumer e-commerce business model). This model is based on companies-market creators, often called shared economy or on-demand service companies (Laudon \& Traver, 2017), which connect sellers and customers i.e., provide and maintain online platforms offering underused assets (e.g. rooms, apartments, houses, etc., usually owned by individuals) via fee- or free-based sharing (Birinci et al., 2018; So et al., 2018). Namely, these platforms can be based on free (i.e. CouchSurfing), reciprocal (e.g. HomeExchange) or rental (e.g. Airbnb, 9flats) peer-to-peer short-term accommodation arrangements (Volgger et al., 2019).

The most important and most famous representative of this model is Airbnb.com. Airbnb started in 2007 as a simple website built by two San Francisco graduate students (Birinci et al., 2018; Wang \& Jeong, 2018). It enables owners to rent their spare beds, rooms, houses or even boats and castles, to any interested client, via web platform or mobile app (Birinci et al., 2018). Airbnb has more than 7 million listings in 100.000 cities and 191 countries, 150 million users with more than 2 million over-night stays each night (Airbnb, 2019; al., 2019). In the last few years, Airbnb has very high growth rates in the EU and US markets of $30 \%$ and more, reaching market shares of $4 \%$ to $5 \%$ (Volgger et al., 2019). On the other hand, eMarketer (2019) estimates that the share of Airbnb in the US accommodation market in 2018 was $19 \%$ (in 2016 it was 13\%), while the share of the hotels has dropped from $80 \%$ in 2016 to $70 \%$ in 2018. Airbnb is the most popular peer-to-peer booking platform in Australia as well (Volgger et al., 2019). Several studies reported that Airbnb mostly influenced the market of lower priced, budget hotels and motels and hotels not focused on business travelers (Zervas et al., 2017; Akbar \& Tracogna, 2018).

One of the most important research questions in this area is why consumers choose online accommodation booking platforms over traditional booking channels i.e., which are the predictors of their intention to use these platforms. The predictors of intentions to purchase travel online were examined by Amaro and Duarte (2016) and as the most important positive determinants they reported attitude and perceived behavioral control, while perceived risk had significant negative impact. Amaro and Duarte (2015) obtained the same results, i.e. they found attitude as the most significant positive predictors of intentions to purchase travel online, followed by compatibility and perceived behavioral control, while perceived risk and trust had negative influence. Tan and Ooi (2018) analyzed antecedents of mobile tourism shopping acceptance and found that perceived enjoyment had the most significant impact on behavioral intention, followed by effort expectancy, social influence, performance expectancy and negative impact of perceived risk.

Lien et al. (2015) pointed out convenience and cost/time saving as two important advantages of online booking and investigated the purchase intentions in online hotel booking. They 
reported brand image, perceived price, and perceived value as three critical determinants, while the impact of trust was not significant. On the other hand, trust and complementarity were found by Li et al. (2017) to be statistically significant predictors of online booking intention, while usability and ease of use were reported as insignificant. Peer-to-peer nature of the sharing economy poses many risks (Cheng et al., 2019), and members on both sides must trust each other i.e. they have to build trustful relationships. Trust is also reported as vital in peer-to-peer accommodation systems adoption by Tussyadiah and Park (2018) and Agag and Eid (2019). In addition, online social influence in the form of user-generated content (such as online reviews) is often found to be a significant determinant of the intention to book an accommodation online (Confente \& Vigolo, 2018), particularly among younger generations. Other studies also reported that consumer-generated content in tourism is often perceived as more trustworthy than the content from official destination websites, travel agents, and mass media (Filieri et al., 2015).

Liu and Zhang (2014) compared hotel website and OTA websites adoption and reported that website quality was found to be a competitive advantage of hotel website over OTA websites, but also that OTA websites perform better in some other aspects from users' perspective. Birinci et al. (2018) compared the attitudes of hotel and Airbnb guests and found that Airbnb guests felt that it provided a more authentic experience compared to hotels. There were no significant differences in perceptions of safety and security, nor regarding time/convenience risk between these two groups. Examining motivators of attitude and behavioral intentions toward Airbnb usage, So et al. (2018) found that price value, enjoyment, home benefits, distrust and social influence significantly explain overall attitude toward Airbnb, while attitude and enjoyment were found to be the most important predictors of intentions.

Finally, Žmuk and Mihajlović (2018) conducted a research based on regression analysis of Eurostat data for 34 European countries (European Union (EU-28) and selected EU candidates) and found that digital skills of users have the greatest impact on the percentage of individuals that use Internet for travel and accommodations services (higher than the development variables like GDP per capita or share of highly educated individuals), as well as that the Western Balkan countries have undeveloped online booking usage for travel and accommodation, compared to the other European countries.

Several studies also examined the influence of socio-demographic factors on habits and attitudes towards online booking systems. For example, Agag and Eid (2019) found that the influence of trust on intention to book peer-to-peer accommodation is stronger for males and for older customers. Confente and Vigolo (2018) reported that younger and middle-aged generations, such as Generation Y and Generation X, had significantly more positive attitude towards online booking than older, silent generation. Examining the behavior of online home-sharing users, including Airbnb users, Smith (2016) reported that these users are usually wealthier, more highly educated, and older than average users. Lien et al. (2015) reported no significant difference between men and women on purchase intentions in online hotel booking, justifying this result by the sample structure, as the most men and women in the sample were young, well-educated and single. Likewise, Confente and Vigolo (2018) found that gender and income were not significant predictors of purchasing intentions in online travel, but also that highly educated tourists, especially in the older generations, are more likely to book a hotel online. Flash Eurobarometer (2016) revealed that in the $28 \mathrm{EU}$ member countries middle-aged consumers (25-54 years old) and more educated consumers were most engaged in the usage of sharing economy services. In their analysis of the Airbnb users renting the entire home, Lutz and Newlands (2018) found that gender doesn't have a significant effect on user behavior, but the influence of education and income levels were both significant and positive. 


\section{Research methodology}

The data on consumer habits and opinions were collected using questionnaire, comprising of three groups of questions. In the first group, there were the questions related to the habits of Serbian travelers, such as how often they travel or book on-line, which websites they prefer, what is their preferred payment method, etc. In the second group, there were questions related to the attitudes about online reservations, i.e., if they consider online booking as safe, if they would recommend in to others, if they are intending to use it in the future, etc. and the answers to these questions were based on 7-point Likert scale. Finally, in the third group, there were demographic questions (gender, age, education, employment, etc.).

The survey was conducted in 2018, in the territory of the Republic of Serbia, using paperbased and on-line questionnaires (Novakovic, 2018). Out of 212 questionnaires collected, 12 were not completed properly and were eliminated from the data analysis, leaving the sample of 200 respondents to be analyzed. The demographic profile of the respondents is presented in the Table 1.

Table 1: Demographic profile of respondents

\begin{tabular}{|l|l|c|c|}
\hline \multirow{2}{*}{ Characteristic } & & Frequency & Percent (\%) \\
\hline \multirow{4}{*}{ Gender } & Men & 92 & 46 \\
\cline { 2 - 4 } & Women & 108 & 54 \\
\cline { 2 - 4 } & Total & 200 & 100 \\
\hline \multirow{5}{*}{ Age } & $20-34$ & 151 & 75.5 \\
\cline { 2 - 4 } & $35-50$ & 38 & 19.0 \\
\cline { 2 - 4 } & Older than 50 & 11 & 5.5 \\
\cline { 2 - 4 } & Total & 200 & 100 \\
\hline \multirow{5}{*}{ Employmention } & Secondary (High School) & 47 & 23.5 \\
\cline { 2 - 4 } & University (Undergraduate) & 94 & 47.0 \\
\cline { 2 - 4 } & Postgraduate & 59 & 29.5 \\
\cline { 2 - 4 } & Total & 200 & 100 \\
\cline { 2 - 4 } & Student & 76 & 38.0 \\
\cline { 2 - 4 } & Employed & 104 & 52.0 \\
\cline { 2 - 4 } & Unemployed & 200 & 4.5 \\
\cline { 2 - 4 } & Retired & & 100 \\
\cline { 2 - 4 } & Total & & \\
\hline
\end{tabular}

Source: Own study

The sample is geared to younger consumers, who are more frequent Internet users in general and more frequent users of electronic commerce in particular (Statistical Office of the Republic of Serbia, 2018).

\section{Results and discussion}

First, general travel habits of the respondents were examined. When asked how many travels they have per year, most of them (44\%) answered that they usually travel three times per year, followed by the answer of five or more times (27\%), two times (19\%) and only once $(10 \%)$. As the main limitations why they do not travel more frequently, the respondents specified the lack of money (56\%) and the lack of time (42\%).

Although significant efforts were made to increase the attractiveness of touristic offer of Serbia, the results of this research show that the majority of the respondents still prefer 
traveling abroad. For example, while $77 \%$ of them book one or two domestic travels and only $3 \%$ book more than four domestic travels per year, the respondents state that only $48 \%$ of them book one or two international travels and $15 \%$ of them travel four or more times abroad.

Financial issues and the lack of time may be responsible also for the selection of the trip type and the duration of the trip. The results show that $48 \%$ of the respondents chose summer holidays as a most preferred trip, followed by visits to other cities - popular "city breaks" (47\%), while only $5 \%$ stated that winter holiday is their most frequent one. In addition, the most frequent duration of the last stay is 3-4 nights (49\%), followed by 5-9 nights (30\%), while only $19 \%$ of the respondents spent 10 or more days on the most recent trip. This previous finding is also in line with the answers to the question about the respondent's budget for the most recent trip, where almost half of them stated that it was in the range of 100-300 Euros. Finally, as the preferred method of payment, Serbian consumers selected payment cards (53\%) and cash (37\%), while $10 \%$ of them preferred alternative payment methods, such as PayPal.

As discussed earlier, the Internet had significant impact on development and availability of various services related to travel and tourism. Today, it is usually the first stop when researching the market and looking for the best offer, and very often the last stop i.e. websites are often used to book and pay for the trip.

The opinion that the Internet is a very important channel for distribution of accommodation is confirmed by the fact that $93 \%$ of the respondents have previously used websites to book their accommodation. The access to global market opens new possibilities to travel, but also the web is sometimes the only channel to reach some offers. Therefore, it is no wonder that Internet is more frequently used to book an accommodation abroad, compared to domestic market. When asked if they dominantly used Internet for booking abroad or in Serbia, 69\% of the respondents chose international bookings.

When asked which of the offered ways of booking an accommodation (both, traditional and web-based) they have previously used, most of the respondents chose platforms for accommodation aggregation, like Booking.com, followed by platforms offering accommodation posted by individuals (e.g. Airbnb.com). The results for the other options are presented in Figure 2 (please bear in mind that this question could have multiple answers, i.e. the total is higher than $100 \%)$.

Figure 2: Percentages of respondents selecting offered booking options

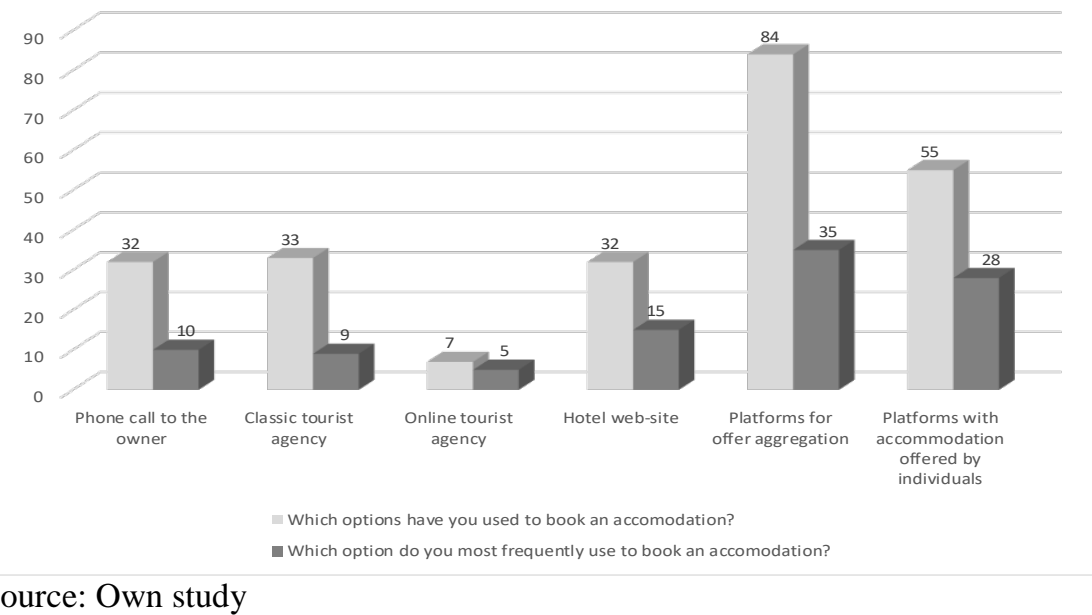

Source: Own study 
Kalinić, Z., Novaković, M. - Online accommodation booking habits and attitudes of Serbian travelers Hotel and Tourism Management, 2019, Vol. 7, No. 2: 11-23.

When asked to specify which web sites they have already used for booking, the far most popular was Booking.com (88\%), followed by Airbnb (57\%), Hostelworld (25\%), Trivago (17\%) and Kayak (5\%). One of the main advantages and main reasons for its popularity among Serbian consumers is that Booking.com offers its interface and results in Serbian language, and the prices could be presented in Serbian dinars.

It is interesting to present the main reasons i.e. the key drivers of Serbian consumers to use online platforms for booking, presented in Figure 3.

Figure 3: Main reasons for using online booking platforms (in \%)

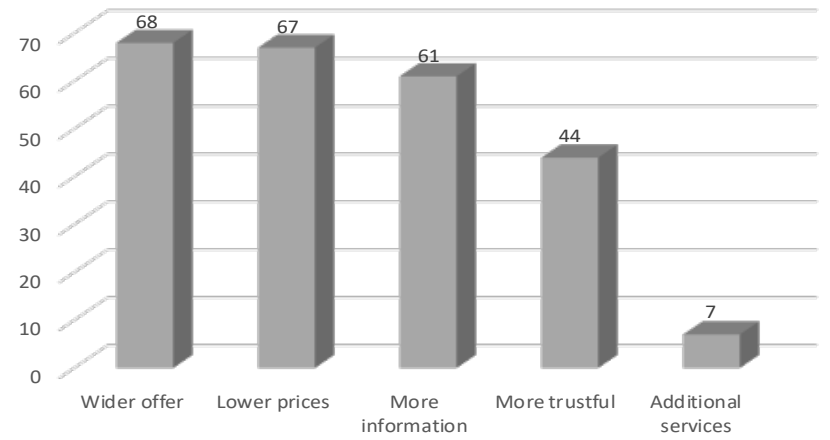

Source: Own study

As it can be seen, two main advantages of online bookings for Serbian consumers are wider offer and lower prices on the web.

Finally, the study investigated consumers' attitudes about some issues of online and offline accommodation booking, and their answers are summarized in Table 2 (Novakovic, 2018).

Table 2: Attitudes of Serbian consumers

\begin{tabular}{|c|c|c|c|c|c|}
\hline Statement & $\begin{array}{c}\text { Total } \\
\mathrm{M}(\mathrm{SD})\end{array}$ & $\begin{array}{c}\text { Women } \\
\mathrm{M}(\mathrm{SD})\end{array}$ & $\begin{array}{c}\text { Man } \\
\mathrm{M}(\mathrm{SD})\end{array}$ & $\mathrm{t}$-value & $\mathrm{p}$-value \\
\hline $\begin{array}{c}\text { I believe it is cheaper to book online } \\
\text { than in classical tourist agencies. }\end{array}$ & $\begin{array}{c}6.03 \\
(1.28)\end{array}$ & $\begin{array}{c}6.08 \\
(1.38)\end{array}$ & $\begin{array}{c}5.94 \\
(1.13)\end{array}$ & -1.015 & 0.311 \\
\hline $\begin{array}{c}\text { I feel safe and I have trust in online } \\
\text { booking platforms. }\end{array}$ & $\begin{array}{c}5.39 \\
(1.29)\end{array}$ & $\begin{array}{c}5.35 \\
(1.44)\end{array}$ & $\begin{array}{c}5.47 \\
(1.08)\end{array}$ & -1.152 & 0.251 \\
\hline $\begin{array}{c}\text { I believe it is possible to find some } \\
\text { offers on the Internet that are not } \\
\text { available in tourist agencies. }\end{array}$ & $\begin{array}{c}6.13 \\
(1.25)\end{array}$ & $\begin{array}{c}6.14 \\
(1.31)\end{array}$ & $\begin{array}{c}6.06 \\
(1.19)\end{array}$ & -1.655 & 0.100 \\
\hline $\begin{array}{c}\text { I can find all relevant information in } \\
\text { the offer on a web page. }\end{array}$ & $\begin{array}{c}5.73 \\
(1.28)\end{array}$ & $\begin{array}{c}5.92 \\
(1.40)\end{array}$ & $\begin{array}{c}5.40 \\
(1.01)\end{array}$ & 2.996 & $0.003^{* *}$ \\
\hline $\begin{array}{c}\text { I believe that I can find more } \\
\text { information about a specific offer on } \\
\text { the Internet than in a tourist agency. }\end{array}$ & $\begin{array}{c}5.55 \\
(1.45)\end{array}$ & $\begin{array}{c}5.71 \\
(1.44)\end{array}$ & $\begin{array}{c}5.28 \\
(1.46)\end{array}$ & 1.555 & 0.121 \\
\hline $\begin{array}{c}\text { I believe that online payment } \\
\text { systems are reliable and trustful. }\end{array}$ & $\begin{array}{c}5.39 \\
(1.30)\end{array}$ & $\begin{array}{c}5.08 \\
(1.44)\end{array}$ & $\begin{array}{c}5.78 \\
(1.04)\end{array}$ & -3.897 & $0.000^{* *}$ \\
\hline $\begin{array}{c}\text { I believe that by booking online I am } \\
\text { saving time. }\end{array}$ & $\begin{array}{c}6.17 \\
(1.30)\end{array}$ & $\begin{array}{c}6.02 \\
(1.46)\end{array}$ & $\begin{array}{c}6.34 \\
(1.07)\end{array}$ & -1.489 & 0.138 \\
\hline $\begin{array}{c}\text { I often advise my friends and } \\
\text { relatives to use online booking. }\end{array}$ & $\begin{array}{c}4.13 \\
(1.90)\end{array}$ & $\begin{array}{c}3.86 \\
(1.99)\end{array}$ & $\begin{array}{c}4.50 \\
(1.76)\end{array}$ & -1.007 & 0.315 \\
\hline $\begin{array}{c}\text { I intend to use online booking even } \\
\text { more in the future. }\end{array}$ & $\begin{array}{c}5.95 \\
(1.39)\end{array}$ & $\begin{array}{c}5.86 \\
(1.47)\end{array}$ & $\begin{array}{c}6.09 \\
(1.23)\end{array}$ & -2.035 & $0.043^{* *}$ \\
\hline
\end{tabular}

Note: $\mathrm{M}-$ mean; SD - Standard Deviation, $* * \mathrm{p}<0.05$. 
The most positive attitudes of Serbian citizens were related to a wider variety of the offer as well as the time-saving and money-saving characteristics of online booking, which is in line with previous results and discussion. The lowest mark was found in the statement about advising one's own environment to use online booking, but one of the reasons for this is that most of them are already using it.

The study also tests if there are any significant differences in attitudes between women and men, and the results for each group, including results of t-test for two independent samples, are presented in Table 2. As in can be noted, significant differences were found in the attitudes in three statements: women believe more than men that web-page with the accommodation offer is the source of all necessary information. On the other hand, men have stronger believes that electronic payment systems in online booking are reliable and secure, and they are more willing to continue and even increase usage of online booking platforms in the future.

The analysis and comparison between younger (than 35 years) and older users showed that the only statistically significant difference was related to the opinion that more information about specific offer is available on the Internet than in tourist agency, where older users had more positive attitudes. In addition, students and highly educated, employed respondents had more positive attitudes and usage intentions towards online accommodation booking systems.

Another analysis presented in this paper compares attitudes of Serbian consumers who mainly book destinations in Serbia with those who mainly use electronic platforms to book their accommodation abroad, and the results of t-test for two independent samples are presented in Table 3 (Novakovic, 2018).

Table 3: Differences between attitudes of Serbian consumers mainly book destinations in Serbia or abroad

\begin{tabular}{|c|c|c|c|c|}
\hline Statement & $\begin{array}{c}\text { Domestic } \\
\text { booking } \\
\text { M (SD) }\end{array}$ & $\begin{array}{c}\text { Booking } \\
\text { abroad } \\
\text { M (SD) }\end{array}$ & t-value & p-value \\
\hline $\begin{array}{c}\text { I believe it is cheaper to book online than } \\
\text { in classical tourist agencies. }\end{array}$ & $\begin{array}{c}5.72 \\
(1.72)\end{array}$ & $\begin{array}{c}6.17 \\
(1.01)\end{array}$ & $-1,876$ & 0,064 \\
\hline $\begin{array}{c}\text { I feel safe and I have trust in online } \\
\text { booking platforms. }\end{array}$ & $\begin{array}{c}4.31 \\
(1.27)\end{array}$ & $\begin{array}{c}5.85 \\
(0.99)\end{array}$ & $-8,431$ & $0,000^{* *}$ \\
\hline $\begin{array}{c}\text { I believe it is possible to find some offers } \\
\text { on the Internet that are not available in } \\
\text { tourist agencies. }\end{array}$ & $\begin{array}{c}4.70 \\
(1.83)\end{array}$ & $\begin{array}{c}5.12 \\
(1.40)\end{array}$ & $-1,589$ & 0,115 \\
\hline $\begin{array}{c}\text { I can find all relevant information in the } \\
\text { offer on a web page. }\end{array}$ & $\begin{array}{c}5.89 \\
(1.38)\end{array}$ & $\begin{array}{c}6.23 \\
(1.18)\end{array}$ & $-1,804$ & 0,073 \\
\hline $\begin{array}{c}\text { I believe that I can find more information } \\
\text { about a specific offer on the Internet than } \\
\text { in a tourist agency. }\end{array}$ & $\begin{array}{c}5.93 \\
(1.39)\end{array}$ & $\begin{array}{c}5.633 \\
(1.22)\end{array}$ & 1,543 & 0,124 \\
\hline $\begin{array}{c}\text { I believe that online payment systems are } \\
\text { reliable and trustful. }\end{array}$ & $\begin{array}{c}5.56 \\
(1.60)\end{array}$ & $\begin{array}{c}5.54 \\
(1.38)\end{array}$ & 0,80 & 0,936 \\
\hline I believe that by booking online I am & $\begin{array}{c}4.69 \\
(1.58)\end{array}$ & $\begin{array}{c}5.69 \\
(1.03)\end{array}$ & $-4,558$ & $0,000 * *$ \\
\hline saving time. & $\begin{array}{c}5.87 \\
(1.74)\end{array}$ & $\begin{array}{c}6.29 \\
(1.04)\end{array}$ & $-1,782$ & 0,079 \\
\hline $\begin{array}{c}\text { I often advise my friends and relatives to } \\
\text { use online booking. }\end{array}$ & $\begin{array}{c}3.48 \\
(1.93)\end{array}$ & $\begin{array}{c}4.41 \\
(1.82)\end{array}$ & $-3,277$ & $0,001 * *$ \\
\hline in the future.
\end{tabular}

Note: M- mean; SD - Standard Deviation, ${ }^{* *} \mathrm{p}<0.05$. 
Statistically significant differences in attitudes are reported in three cases. First, consumers who mainly book abroad feel safer and have more trust than "domestic" consumers. The main reason for this is probably because when booking abroad, consumers use well-known and well-established platforms, such as Booking and Airbnb, while the lack of dominant, trustful domestic online platform means that most of domestic bookings is performed on local, less-known websites and platforms, which are usually perceived as less secure. Second, consumers who mainly book abroad have a stronger belief that they save time by booking online. Possible explanation for this finding is that, for domestic travels, booking by phone call is a good and sometimes even faster alternative to online booking, while for booking abroad it would be very difficult and time-consuming to use other methods, such as phone call or e-mail. Finally, consumers who mainly book abroad have more positive attitudes towards future usage of online booking platforms. The possible reason is similar to the previous finding - alternatives for booking abroad are far more complicated, compared to the alternative ways to book accommodation locally.

\section{Conclusion}

Digital travel sales are one of the most developed and most frequently used forms of ecommerce worldwide. The paper presents a study of the habits and attitudes of Serbian consumers regarding online accommodation booking. The results show that Serbian consumers frequently use digital platforms to book their travels. The most popular booking platform in Serbia is Booking.com followed by Airbnb. In addition, Serbian consumers use online booking more when staying abroad than for domestic stays. Mainly due to economic reasons, they usually book shorter and cheaper travels and stays. Wider variety of the offer and time and money savings are two main benefits for Serbian respondents, and these findings are in line with previous results (Lien et al., 2015).

The study also reported minor differences in attitudes among different socio-demographic groups. For example, men's attitudes towards security and reliability of electronic payment systems in online booking are more positive. Also, men are more willing to increase their usage of online booking platforms in the future. In addition, respondents with higher education and income levels are more willing to use online accommodation booking systems, which is also in line with previous studies (Smith, 2016).

One of the managerial implications of the study is that, since women perceive electronic payment systems in online booking as not so secure (compared to men's attitudes), additional efforts in persuading this demographic group that these systems are completely safe and trustful should be made. This can be done by additional digital marketing campaigns targeting only female consumers. Another implication is that, since Serbian consumers perceive international online booking platforms as much more reliable than domestic websites, additional efforts should be made to build and maintain trust in local booking websites, through trustmarks and additional support of national tourist organization.

Finally, the study has several limitations. First of all, the sample is geared towards younger, more educated consumers i.e. it better represents population of Internet users than general Serbian population. In addition, it only analyses the attitudes to online booking platforms. Some further studies should include other travel products, such as flight tickets, rent-a-car, etc. Finally, the study was performed as cross-sectional, i.e. at a single point in time. It would be interesting to perform longitudinal study i.e. to explore how consumers' habits and attitudes evolve over time. 


\section{References}

1. Agag, G., \& Eid, R. (2019). Examining the antecedents and consequences of trust in the context of peer-to-peer accommodation. International Journal of Hospitality Management, 81, 180-192. https://doi.org/10.1016/j.ijhm.2019.04.021

2. Airbnb. (2019). Airbnb Fast Facts. Retrieved November 4, 2019 from https://news.airbnb.com/fast-facts/

3. Akbar, Y. H., \& Tracogna, A. (2018). The sharing economy and the future of the hotel industry: Transaction cost theory and platform economics. International Journal of Hospitality Management, 71, 91-101. https://doi.org/10.1016/j.ijhm.2017.12.004

4. Amaro, S., \& Duarte, P. (2015). An integrative model of consumers' intentions to purchase travel online. Tourism Management, 46, 64-79. http://dx.doi.org/10.1016/j.tourman.2014.06.006

5. Amaro, S., \& Duarte, P. (2016). Travellers' intention to purchase travel online: integrating trust and risk to the theory of planned behaviour. Anatolia, 27(3), 389-400. https://doi.org/10.1080/13032917.2016.1191771

6. Bilgihan, A., \& Bujisic, M. (2015). The effect of website features in online relationship marketing: A case of online hotel booking. Electronic Commerce Research and Applications, 14, 222-232. http://dx.doi.org/10.1016/j.elerap.2014.09.001

7. Birinci, H., Berezina, K., \& Cobanoglu, C. (2018). Comparing customer perceptions of hotel and peer-to-peer accommodation advantages and disadvantages. International Journal of Contemporary Hospitality Management, 30(2), 1190-1210. https://doi.org/10.1108/IJCHM-09-2016-0506

8. Booking. (2019). About Booking.com. Retrieved October 23, 2019 from https://www.booking.com/content/about.sr.html?aid=356980

9. Chang, Y-W., Hsu, P-Y., \& Lan, Y-C. (2019). Cooperation and competition between online travel agencies and hotels. Tourism Management, 71, 187-196. https://doi.org/10.1016/j.tourman.2018.08.026

10. Chaw, L. Y., \& Tang, C. M. (2019). Online accommodation booking: what information matters the most to users? Information Technology \& Tourism, First online since 27 May 2019. https://doi.org/10.1007/s40558-019-00146-1

11. Chen, Y., Liu, S., Tussyadiah, I., Abidin, H. Z., \& Zarezadeh, Z. (2019). Inferences and Decision Heuristics in Peer-to-Peer Accommodation Booking. e-Review of Tourism Research, 16(2/3), 53-61.

12. Cheng, X., Fu, S., Sun, J., Bilgihan, A., \& Okumus, F. (2019). An investigation on online reviews in sharing economy driven hospitality platforms: A viewpoint of trust. Tourism Management, 71, 366-377. https://doi.org/10.1016/j.tourman.2018.10.020

13. Confente, I., \& Vigolo, V. (2018). Online travel behaviour across cohorts: The impact of social influences and attitude on hotel booking intention. International Journal of Tourism Research, 20(5), 660-670. https://doi.org/10.1002/jtr.2214

14. eMarketer. (2017). Digital Travel Sales Worldwide, 2017-2022. Retrieved October 25, 2019 from https://www.emarketer.com/chart/221442/digital-travel-sales-worldwide2017-2022-billions-change

15. eMarketer. (2018). Worldwide Digital Travel Sales: eMarketer's Estimates for 20162021. Retrieved October 25, 2019 from https://www.emarketer.com/Report/WorldwideDigital-Travel-Sales-eMarketers-Estimates-20162021/2002089

16. eMarketer. (2019). The Weekly Listen: Airbnb's IPO and Facebook Acquires 'MindReading Wristband' Company. Retrieved October 25, 2019 from https://www.emarketer.com/content/podcast-the-weekly-listen-airbnb-ipo-and-facebookacquires-mind-reading-wristband-company 
17. Eurostat. (2018a). Individuals - internet use. Eurostat database, Table [isoc_ci_ifp_iu]. Retrieved October 23, 2019 from https://ec.europa.eu/eurostat/data/database

18. Eurostat. (2018b). Individuals - internet activities. Eurostat database, Table [isoc_ci_ac_i]. Retrieved October 23, 2019 from https://ec.europa.eu/eurostat/data/database

19. Eurostat. (2018c). Individuals - collaborative economy. Eurostat database, Table [isoc_ci_ce_i]. Retrieved October 23, 2019 from https://ec.europa.eu/eurostat/data/database

20. Filieri, R., Alguezaui, S., \& McLeay, F. (2015). Why do travelers trust TripAdvisor? Antecedents of trust towards consumer-generated media and its influence on recommendation adoption and word of mouth. Tourism Management, 51, 174-185. https://doi.org/10.1016/j.tourman.2015.05.007

21. Flash Eurobarometer (2016). The use of collaborative platforms. Retrieved November 10, 2019 from http://data.europa.eu/euodp/en/data/dataset/S2112_438_ENG

22. Laudon, K. C., \& Traver, C. G. (2017). E-commerce 2017: business. technology. society. Pearson Education.

23. Li, L., Peng, M., Jiang, N., \& Law, R. (2017). An empirical study on the influence of economy hotel website quality on online booking intentions. International Journal of Hospitality Management, 63, 1-10. http://dx.doi.org/10.1016/j.ijhm.2017.01.001

24. Lien, C-H., Wen, M-J., Huang, L-C., \& Wu, K-L. (2015). Online hotel booking: The effects of brand image, price, trust and value on purchase intentions. Asia Pacific Management Review, 20, 210-218. http://dx.doi.org/10.1016/j.apmrv.2015.03.005

25. Liu, J. N. K., \& Zhang, E. Y. (2014). An investigation of factors affecting customer selection of online hotel booking channels. International Journal of Hospitality Management, 39, 71-83. http://dx.doi.org/10.1016/j.ijhm.2014.01.011

26. Lutz, C., \& Newlands, G. (2018). Consumer segmentation within the sharing economy: The case of Airbnb. Journal of Business Research, 88, 187-196. https://doi.org/10.1016/j.jbusres.2018.03.019

27. Novakovic, M. (2018). Research on consumer attitudes on global electronic booking platforms in tourism (Unpublished master's thesis). Faculty of Economics, University of Kragujevac, Serbia.

28. Smith, A. (2016). Shared, collaborative and on demand: The new digital economy. Washington, DC: Pew Internet \& American Life Project. Retrieved November 10, 2019 from https://www.pewresearch.org/internet/2016/05/19/the-new-digital-economy/

29. So, K. K. K., Oh, H., \& Min, S. (2018). Motivations and constraints of Airbnb consumers: Findings from a mixed-methods approach. Tourism Management, 67, 224236. https://doi.org/10.1016/j.tourman.2018.01.009

30. Statista. (2019). Online Travel Booking Worldwide. Retrieved October 25, 2019 from https://www.statista.com/outlook/262/100/online-travel-booking/worldwide\#marketrevenue

31. Statistical Office of the Republic of Serbia. (2018). Usage of Information and Communication Technologies in the Republic of Serbia, 2018. Retrieved June 14, 2019 from http://publikacije.stat.gov.rs/G2018/PdfE/G201816013.pdf.

32. Tan, G. W-H., \& Ooi, K-B. (2018). Gender and age: Do they really moderate mobile tourism shopping behavior? Telematics and Informatics, 35, 1617-1642. https://doi.org/10.1016/j.tele.2018.04.009

33. Tussyadiah, I. P., \& Park, S. (2018). When guests trust hosts for their words: Host description and trust in sharing economy. Tourism Management, 67, 261-272. https://doi.org/10.1016/j.tourman.2018.02.002

34. Volgger, M., Taplin, R., \& Pforr, C. (2019). The evolution of 'Airbnb-tourism': Demand-side dynamics around international use of peer-to-peer accommodation in 
Australia. Annals of Tourism Research, 75, 322-337. https://doi.org/10.1016/j.annals.2019.02.007

35. Wang, C., \& Jeong, M. (2018). What makes you choose Airbnb again? An examination of users' perceptions toward the website and their stay. International Journal of Hospitality Management, 74, 162-170. https://doi.org/10.1016/j.ijhm.2018.04.006

36. Zervas, G., Proserpio, D., \& Byers, J. W. (2017). The Rise of the Sharing Economy: Estimating the Impact of Airbnb on the Hotel Industry. Journal of Marketing Research, 54(5), 687-705. https://doi.org/10.1509/jmr.15.0204

37. Žmuk, B., \& Mihajlović, I. (2018). Online booking for travel and accommodation influenced by economic and digital development level: Position of the Western Balkan countries within Europe. Croatian Review of Economic, Business and Social Statistics, 4(2), 86-98. https://doi.org/10.2478/crebss-2018-0016 